\title{
Daya hambat ekstrak buah mengkudu terhadap pertumbuhan Candida albicans
}

\author{
Muhammad Ilyas \\ Bagian Ilmu Kesehatan Gigi Masyarakat \\ Fakultas Kedokteran Gigi Universitas Hasanuddin \\ Makassar, Indonesia
}

\begin{abstract}
Mengkudu contains saponin, flavanoid, atsiri oil and alkaloid that stated as antibacterial and antifungal. This study was a laboratory experimental with time series design that used rejuvenatal Candida albicans as subjects and was held in Microbiology Laboratory of Medical Faculty of UNHAS. This study was to find out the minimal inhibiting concentration and force of mengkudu based on growth concentration of Candida albicans. SPSS program version 11.5 with Kruskal-Wallis test and Mann Witney test are used for data analysis. The result was Candida albicans had minimal inhibiting concentration at $12 \%$ and the maximal at $16 \%$.
\end{abstract}

Key word: Mengkudu, Candida albican, minimal inhibition concentrations.

\begin{abstract}
ABSTRAK
Mengkudu mengandung saponin, flavonoid, minyak atsiri dan alkaloid yang dinyatakan sebagai antibakteri dan antijamur. Penelitian ini bersifat eksperimen laboratorium dengan rancangan time series design, dengan menggunakan isolat Candida albicans yang telah diremajakan. Penelitian dilakukan di Laboratorium Mikrobiologi Fakultas Kedokteran Unhas. Penelitian ini bertujuan untuk mengetahui konsentrasi hambat minimal dan daya hambat sari buah mengkudu berdasarkan konsentrasi terhadap pertumbuhan Candida albicans. Analisis data memakai program SPSS versi 11,5 dengan Kruskal-Wallis test dan Mann Whitney test. Hasil penelitian menunjukkan bahwa sari buah mengkudu $12 \%$ mempunyai daya hambat minimal terhadap pertumbuhan Candida albicans dan terbesar pada konsentrasi $16 \%$.
\end{abstract}

Kata kunci: Mengkudu, Candida albicans, konsentrasi hambat minimal.

Koresponden: Muhammad Ilyas, Bagian Ilmu Kesehatan Gigi Masyarakat, Fakultas Kedokteran Gigi Universitas Hasanuddin, Jl. Perintis Kemerdekaan Km.10, Tamalanrea, Makassar 90245, Indonesia.

\section{PENDAHULUAN}

Mengkudu (Morinda citrifolia linn) merupakan tanaman daerah tropis yang sejak ribuan tahun dimanfaatkan manusia untuk mengobati berbagai penyakit. Mengkudu sudah diakui oleh Badan Pengawas Obat dan Makanan (BPOM)sebagai tanaman obat. Mengkudu termasuk dalam tujuh komoditi unggulan dalam pengembangan jangka pendek (5 tahun), selain temulawak, kunyit, jati belanda, sambiloto, daun salam, dan cabe jawa. ${ }^{1-3}$

Bagian tanaman mengkudu yang paling banyak dimanfaatkan adalah buahnya, sedangkan sediaannya yang paling popular adalah dalam bentuk jus. ${ }^{2,45}$ Penelitian sebelumnya manyatakan bahwa buah mengukudu mengandung saponin, flavonoid, minyak atsiri dan alkaloid yang dapat digunakan sebagai bahan kosmetik, perawatan 
kulit dan rambut. Adapun efek farmakologis yang telah terbukti yaitu imunomodulasi, reparasi dan peremajaan sel, vasoproteksi, antioksidan, hepatoproteksi, antibiotik dan anti jamur.,

Infeksi jamur pada rongga mulut yang paling sering terjadi disebabkan oleh Candida sp. dan spesies Actinomycetes. Candida albicans adalah salah satu spesies Candida yang merupakan organisma komensal dalam rongga mulut, merupakan jamur dimorfik yaitu patogen oportunistik dan merupakan flora normal di rongga mulut. Dilaporkan adanya Candida albicans sebanyak 5,7\% dari 140 bayi umur 1 hari, $14,2 \%$ pada umur 7 hari dan sebanyak $82 \%$ pada umur 4 minggu. Prevalensi tersebut selanjutnya menurun menjadi 50\% pada bayi umur 1 tahun. Candida albicans dapat menimbulkan kelainan atau infeksi di dalam rongga mulut yang tampak dalam beberapa bentuk, yang sering disebut sebagai moniliasis, kandidiasis, atau kandidosis. ${ }^{5-8}$

Candida albicans adalah suatu ragi lonjong dan bertunas yang menghasilkan pseudomiselium baik dalam biakan maupun dalam jaringan dan eksudat. Ragi ini adalah anggota flora normal selaput mukosa, saluran pernapasan, saluran pencernaan, dan genitalia wanita. ${ }^{9-11}$

Walaupun Candida albicans merupakan komponen normal dari flora rongga mulut, kadang-kadang pada suatu waktu bisa menimbulkan penyakit. Faktor predisposisi infeksi Candida albicans adalah diabetes melitus, kelemahan menyeluruh, imunodefisiensi, kateter intravena atau air kemih yang terpasang terus menerus, penyalahgunaan narkotika intravena, pemberian antimikroba (yang mengubah flora bakteri normal) dan kortikosteroid. Faktor-faktor lain yang juga memicu pertumbuhan Candida adalah kehamilan, defisiensi zat besi, asam folat, vitamin B12, penggunaan kemoterapi pada kanker, dan pada keadaan stres dan depresi. ${ }^{9,12}$
Berdasarkan latar belakang tersebut, maka timbul pertanyaan tentang konsentrasi hambat minimal ekstrak buah mengkudu terhadap pertumbuhan Candida albicans, dan tentang daya hambat ekstrak buah mengkudu berdasarkan konsentrasi terhadap pertumbuhan Candida albicans. Untuk itu, hasil penelitian ini diharapkan dapat memberikan informasi tentang peran mengkudu sebagai anti jamur sehingga dapat dijadikan terapi alternatif dalam bidang kedokteran gigi untuk menghambat pertumbuhan jamur Candida albicans.

Penelitian ini bertujuan untuk mengetahui konsentrasi hambat minimal ekstrak buah mengkudu terhadap pertumbuhan Candida albicans, dan daya hambat ekstrak buah mengkudu berdasarkan konsentrasi terhadap pertumbuhan Candida albicans.

\section{BAHAN DAN METODE}

Penelitian ini merupakan eksperimen laboratorium dengan rancangan time series design. Penelitian dilakukan di Laboratorium Mikrobiologi Fakultas Kedokteran Unhas pada bulan Desember 2006. Subjek penelitian yaitu isolat Candida albicans yang telah diremajakan dengan jumlah perlakuan dalam 20 pencadang silinder dengan 4 kali replikasi. Setiap cawan petri berisi 5 pencadang yang masing-masing berisi $10 \%, 12 \%, 14 \%, 16 \%$, dan povidone iodine $10 \%$ sebagai kontrol positif.

Kriteria penilaian penilaian konsentrasi hambat minimal ekstrak buah mengkudu dapat dilihat pada tabung dengan konsentrasi terendah yang pertama kali terlihat jernih. Sedangkan uji daya hambat ekstrak buah mengkudu terhadap pertumbuhan Candida albicans diukur dari luas zona inhibisi. Luas zona inhibisi merupakan diameter daerah yang bening. Pengukuran dilakukan 3 kali dari arah yang berbeda dengan 
menggunakan kaliper. Luas zona inhibisi sebagai berikut terlihat pada gambar 1 .

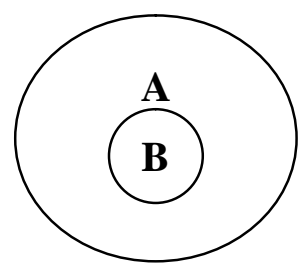

Gambar 1. Luas A: luas daerah berwarna bening. Luas B: luas pencadang yang berisi larutan uji (diameter $6 \mathrm{~mm}$ ). Luas zona inhibisi: diameter $(\mathrm{A}+\mathrm{B})$.

Analisis data Menggunakan program SPSS versi 11,5 dengan analisis Kruskal-Wallis test untuk mengetahui perbedaan daya hambat dan Mann Whitney test untuk mengetahui perbedaan daya hambat berdasarkan konsentrasi.

\section{HASIL}

Dari penelitian mengenai daya hambat ekstrak buah mengkudu terhadap pertumbuhan Candida albicans diperoleh hasil bahwa konsentrasi hambat minimal sari buah mengkudu terhadap pertumbuhan Candida albicans adalah $12 \%$. Penentuan konsentrasi hambat minimal (KHM) dapat kita lihat pada gambar 2 dan 3.

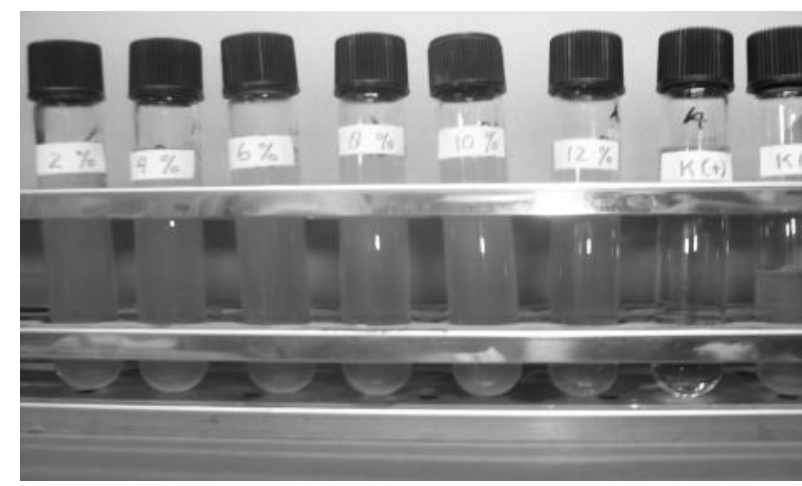

Gambar 2. Hasil uji penentuan konsentrasi hambat minimal ekstrak buah mengkudu terhadap pertumbuhan Candida albicans.
Konsentrasi hambat minimal yang diperoleh kemudian dilanjutkan dengan uji daya hambat bakteri menggunakan pencadang dengan metode difusi dalam cawan petri untuk melihat luas daerah zona inhibisi dengan mengambil KHM (12\%), satu konsentrasi di bawah KHM (10\%), dan dua konsentrasi di atas KHM (14\% dan 16\%) serta kontrol positif (tabel 1).

Tabel 1. Hasil dari uji konsentrasi hambat minimal (KHM) ekstrak buah mengkudu terhadap pertumbuhan Candida albicans.

\begin{tabular}{ccc}
\hline \multirow{2}{*}{ Konsentrasi (\%) } & \multicolumn{2}{c}{ KHM } \\
\cline { 2 - 3 } & Tidak & Ya \\
\hline $2 \%$ & $\sqrt{ }$ & - \\
$4 \%$ & $\sqrt{ }$ & - \\
$6 \%$ & $\sqrt{ }$ & - \\
$8 \%$ & $\sqrt{ }$ & - \\
$10 \%$ & $\sqrt{ }$ & - \\
$12 \%$ & - & $\sqrt{ }$ \\
\hline
\end{tabular}

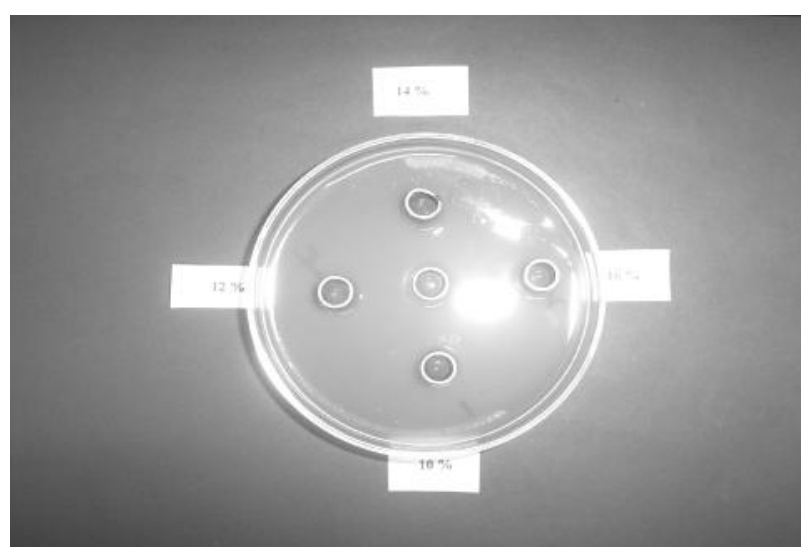

Gambar 3. Hasil uji daya hambat ekstrak buah mengkudu pada konsentrasi $10 \%, 12 \%$, $14 \%, 16 \%$ dan kontrol positif.

Dari hasil uji daya hambat yang dilakukan, maka dilakukan analisis data untuk membedakan apakah perbedaan daya hambat tersebut bermakna atau tidak dengan uji Kruskal-Wallis. Hasil yang diperoleh terlihat pada tabel 2. 
Tabel 2. Hasil pengamatan zona inhibisi ekstrak buah mengkudu terhadap Candida albicans setelah 24 jam dan 48 jam.

\begin{tabular}{ccccccccc}
\hline & \multicolumn{9}{c}{ 24 Jam } & \multicolumn{7}{c}{ 48 Jam } \\
\cline { 2 - 9 } Konsentrasi & $\mathrm{N}$ & Mean & SD & $P$ & N & Mean & SD & $P$ \\
\hline $10 \%$ & 4 & 12,49 & 0,43 & & 4 & 12,87 & 0.48 & \\
$12 \%$ & 4 & 13,83 & 1,38 & & 4 & 14,12 & 1,31 & \\
$14 \%$ & 4 & 14,93 & 1,22 & $0,010^{*}$ & 4 & 15,25 & 1,26 & $0,006^{*}$ \\
$16 \%$ & 4 & 16,54 & 0,83 & & 4 & 17 & 0,57 & \\
Kontrol & 4 & 15,95 & 0,93 & & 4 & 16,25 & 0,86 & \\
\hline
\end{tabular}

Keterangan: Uji Kruskal-Wallis $\rightarrow *$ signifikan $\mathrm{P}<0,05$

Berdasarkan hasil analisis statistik menggunakan uji Kruskal Wallis diperoleh hasil yang signifikan $(\mathrm{p}<0,05)$ pada pengamatan 24 jam dan 48 jam. Ini berarti ada perbedaan yang bermakna berbagai konsentrasi sari buah mengkudu dalam menghambat pertumbuhan Candida albicans. Untuk mengetahui pasangan perlakuan yang bermakna dilanjutkan dengan uji Mann-Whitney yang terlihat pada tabel 3 dan 4.

Tabel 3. Perbedaan daya hambat sari buah mengkudu dalam berbagai konsentrasi dan obat kumur betadine setelah 24 jam.

\begin{tabular}{cccccc}
\hline Perlakuan & $10 \%$ & $12 \%$ & $14 \%$ & $16 \%$ & Kontrol \\
\hline $10 \%$ & - & 0,059 & $0,021^{*}$ & $0,021^{*}$ & $0,021^{*}$ \\
$12 \%$ & - & - & 0,248 & $0,043^{*}$ & $0,043^{*}$ \\
$14 \%$ & - & - & - & 0,083 & 0,386 \\
$16 \%$ & - & - & - & - & 0,468 \\
Kontrol & - & - & - & - & -
\end{tabular}

Keterangan: Uji Mann-Whitney $*=$ signifikan $\mathrm{P}$ $<0,05$

Dari tabel 3 dan 4 terlihat bahwa pada seluruh pasangan perlakuan terdapat perbedaan yang bermakna $(p<0,005)$, kecuali perbandingan antara konsentrasi $10 \%$ dengan $12 \%$, konsentrasi $12 \%$ dengan $14 \%$, konsentrasi $14 \%$ dengan $16 \%$, konsentrasi $14 \%$ dengan kontrol, dan konsentrasi $16 \%$ dengan kontrol.

Tabel 4. Perbedaan daya hambat ekstrak buah mengkudu dalam berbagai konsentrasi dan obat kumur betadine setelah 48 jam.

\begin{tabular}{cccccc}
\hline Perlakuan & $10 \%$ & $12 \%$ & $14 \%$ & $16 \%$ & Kontrol \\
\hline $10 \%$ & - & 0,078 & $0,019 *$ & $0,019 *$ & $0,019^{*}$ \\
$12 \%$ & - & - & $0,189^{*}$ & $0,019 *$ & $0,042^{*}$ \\
$14 \%$ & - & - & - & 0,078 & 0,294 \\
$16 \%$ & - & - & - & - & 0,215 \\
Kontrol & - & - & - & - & - \\
\hline
\end{tabular}

Keterangan: Uji Mann-Whitney *= signifikan $\mathrm{P}<0,05$

\section{PEMBAHASAN}

Pada gambar 2 dapat dilihat hasil dari uji KHM sari buah mengkudu yang digunakan. Hasil dari uji tersebut menunjukkan bahwa KHM dari sari buah mengkudu adalah $12 \%$, yaitu kekeruhan tidak terlihat pada konsentrasi tersebut. Setelah memperoleh KHM tersebut kemudian dilakukan uji daya hambat dengan menggunakan KHM, 1 konsentrasi di bawah KHM, dan 2 konsentrasi di atas KHM, serta kontrol positif (betadine kumur). Hal ini sesuai dengan penelitian sebelumnya yang menyatakan bahwa sari buah mengkudu dapat menghambat pertumbuhan Candida albicans yang disebabkan oleh adanya kandungan senyawa kimia yaitu flavonoid, minyak atsiri, dan saponin. Senyawa kimia flavonoid, minyak atsiri dan 
saponin berfungsi sebagai antibakteri dan antijamur. $5,13,14$

Flavonoid yang merupakan senyawa fenol dapat menyebabkan kerusakan membran sel sehingga terjadi kebocoran isi sel dan berakibat lisis. Sedangkan saponin bersifat sebagai surfaktan yang berbentuk polar yang dapat memecah lapisan lemak pada membran sehingga menyebabkan gangguan permeabilitas membran sel kuman. Hal tersebut menyebabkan pemasukan bahan atau zatzat yang diperlukan dapat terganggu akhirnya sel membengkak dan pecah. Minyak atsiri menyebabkan denaturasi protein, yaitu merubah molekul protein atau asam lemak, menghambat kerja enzim dan mengganggu sintesis asam nuklaet. ${ }^{3.10,15,16}$

Pada gambar 3 memperlihatkan luas zona inhibisi dimana yang terbesar pada konsentrasi 16 $\%$ dan yang terkecil pada konsentrasi $10 \%$. Hal ini menunjukkan bahwa semakin besar konsentrasi yang digunakan maka luas zona inhibisinya semakain luas, hal ini sesuai dengan penelitian sebelumnya yang mengatakan bahwa semakin tinggi konsentrasi suatu zat kimia yang digunakan maka mempunyai kemampuan lebih besar dibanding yang endah dalam menghambat zat organik $^{17}$

Pada tabel 2 terlihat bahwa kelima konsentrasi yang digunakan memiliki daya hambat yang berbeda-beda. Pada pengamatan terlihat rata-rata luas zona inhibisi terkecil pada konsentrasi $10 \%$ $(12,49 \mathrm{~mm})$ dan terbesar pada konsentrasi $16 \%$ (16,54 mm). Sedangkan pada pengamatan 48 jam, rata-rata luas zona inhibisi terkecil pada konsentrasi $10 \%(12,87 \mathrm{~mm})$ dan terbesar pada konsentrasi $16 \%$ (17 mm). Zona hambatan yang terbentuk semakin besar bila konsentrasi sari buah mengkudu yang digunakan juga semakin besar. Perbedaan daya hambat tersebut diuji secara statistik menggunakan uji Kruskal Wallis. Hasil uji tersebut menunjukkan perbedaan daya hambat yang bermakna.

Pada tabel 3 dan 4 memperlihatkan perbandingan antara seluruh konsentrasi sari buah mengkudu dan kontrol (betadine kumur) dengan menggunakan uji Mann-Whitney. Diperoleh hasil bahwa pada konsentrasi $14 \%$ dan $16 \%$ setelah 24 jam tidak ada perbedaan yang bermakna. Artinya diantara konsentrasi tersebut sama efektifnya dalam menghambat pertumbuhan Candida albicans. Hal ini dapat disebabkan karena perbedaaan konsentrasi yang kecil yaitu $2 \%$. Konsentrasi $10 \%$ dan $12 \%$ bila dibandingkan dengan kontrol memiliki perbedaan yang bermakna tetapi pada konsentrasi $14 \%$ dan $16 \%$ dengan kontrol tidak memiliki perbedaan yang bermakna. Hal ini berarti bahwa betadine kumur yang digunakan sebagai pembanding lebih efektif dibandingkan sari buah mengkudu pada konsentrasi $10 \%$ dan $12 \%$ tetapi sama efektifnya dengan sari buah mengkudu pada konsentrasi $14 \%$ dan $16 \%$ dalam menghambat pertumbuhan Candida albicans. ${ }^{1}$

\section{SIMPULAN}

Dari penelitian mengenai daya hambat ekstrak buah mengkudu terhadap pertumbuhan Candida albicans dapat disimpulkan bahwa konsentrasi hambat minimal ekstrak buah mengkudu yang dapat menghambat pertumbuhan Candida albicans adalah $12 \%$, yang meningkat sesuai dengan peningkatan konsentrasi. Selain itu, didapatkan daya hambat ekstrak buah mengkudu terbesar pada konsentrasi $16 \%$ dan terkecil pada konsentrasi $10 \%$.

\section{SARAN}

Perlu dilakukan uji klinis lebih lanjut untuk mengetahui efek antimikroba dari sari buah mengkudu di dalam rongga mulut. 


\section{DAFTAR PUSTAKA}

1. Indiani SR, Soeprapto H. Efek perasan buah mengkudu sebagai perendam resin akrilik terhadap keberadaan Candida albicans. Majalah Kedokteran Gigi FKG Unair. Edisi Khusus Temu Ilmiah Nasional III; 2003. p.13.

2. Toni H. Mengkudu; khasiat dan peluang usahanya. Semarang: CV. Aneka Ilmu; 2003. p. 1, 5, 6, 22-3.

3. Boedirahardjo R, Dewanti I. Kemampuan Morinda citrifolia $L$ dalam menurunkan sel radang pada rongga mulut mencit yang diinduksi luka tusuk. Majalah Kedokteran Gigi FKG Unair. Edisi Khusus Temu Ilmiah Nasional IV; 2005. p. 321-5.

4. Sjabana D, Bahalwan RR. Pesona tradisional dan ilmiah mengkudu. Jakarta: Penerbit Salemba Medika; 2002. p. 2, 4, 6, 7, 9-11, 378,45 .

5. Nasution MA. Beberapa macam infeksi jamur pada rongga mulut, kulit dan kelamin.Wahana Medik 1990; 4 (9): 14.

6. Rahayu RP, Rahardjo MB. Prevalensi infeksi Candida pada penderita diabetes mellitus. Majalah Kedokteran Gigi. Edisi Khusus Temu Ilmiah Nasional IV; 2005. p. 218.

7. Winasa IG. Prevalensi Candida albicans pada Panti Werda di Bali. Majalah Kesehatan Gigi Indonesia $1997 ; 1(4): 24$.

8. Jawetz, Melnick, Adelberg. Mikrobiologi kedokteran. Edisi 20. Alih Bahasa: Nugroho E, Maulani RF. Jakarta: EGC ; 1997. p.627.

9 Zhang W. Tahitian noni juice is Included. Available at: http://www.prweb.com/releases. Diakses: 14 Juli 2005.
10. Sabir A. Pemanfaatan flavonoid di bidang kedokteran gigi. Majalah Kedokteran Gigi. Edisi Khusus Temu Ilmiah Nasional IV; 2005; p.81.

11. Anonim. Tanaman obat Indonesia. Available at : http://www.iptek.net.id. Diakses : 17 Maret 2005.

12. Ying WM, West BJ, Jensen CJ, Nowicki D, Chen SU, Palu AK. Morinda citrifolia (Noni): A literature review and recent advances in noni research. Available at: http://www.noniland.com. Diakses: 7 Maret 2005.

13. Lestari RP, Regina TC, Tandelilin, Handajani J. Efektifitas minyak atsiri lengkuas putih (Alpinia galanga) terhadap pertumbuhan Candida albicans 302 yang resisten multiantibiotik. Indonesian J Dent 2005; 12 (1): 25.

14. Anonym. Mengkudu (Morinda citrifolia L.). Available at: http://www.tempointeraktif.com/kliniknet/ artikel/mengkudu. Diakses: 7 Maret 2005.

15. Siswomihardjo W. Saponin getah Plumeria acuminate ait. Sebagai alternatif bahan devitalisasi jaringan pulpa gigi. Majalah Kedokteran Gigi. Edisi Khusus Temu Ilmiah Nasional IV; 2005. p.13.

16. Anonym. Saponin. Available at: http//www.micro.magnet.fsu.edu/phytochemic al/ pages/saponin.html. Diakses: 3 Agustus 2005. 